Review

\title{
The Application of Nitric Oxide for Ocular Hypertension Treatment
}

\author{
Binze Han, Maomao Song, Liping Li, Xinghuai Sun * and Yuan Lei *
}

Citation: Han, B.; Song, M.; Li, L.; Sun, X.; Lei, Y. The Application of Nitric Oxide for Ocular Hypertension Treatment. Molecules 2021, 26, 7306. https://doi.org/10.3390/molecules 26237306

Academic Editors: Rosa Amoroso, Roberta Fruttero, Elena Gazzano and Federica Sodano

Received: 24 September 2021 Accepted: 25 November 2021 Published: 1 December 2021

Publisher's Note: MDPI stays neutral with regard to jurisdictional claims in published maps and institutional affiliations.

Copyright: (c) 2021 by the authors. Licensee MDPI, Basel, Switzerland. This article is an open access article distributed under the terms and conditions of the Creative Commons Attribution (CC BY) license (https:// creativecommons.org/licenses/by/ $4.0 /)$.
Department of Ophthalmology \& Visual Science, Eye \& ENT Hospital, Shanghai Medical College, Fudan University, Shanghai 200031, China; Hanbz2014@126.com (B.H.); 17111260011@fudan.edu.cn (M.S.); 21111260010@fudan.edu.cn (L.L.)

* Correspondence: xhsun@shmu.edu.cn (X.S.); lilian0167@hotmail.com (Y.L.)

Abstract: Despite of various therapeutic methods for treating ocular hypertension and glaucoma, it still remains the leading cause of irreversible blindness. Intraocular pressure (IOP) lowering is the most effective way to slow disease progression and prevent blindness. Among the ocular hypotensive drugs currently in use, only a couple act on the conventional outflow system, which is the main pathway for aqueous humor outflow and the major lesion site resulting in ocular hypertension. Nitric oxide (NO) is a commendable new class of glaucoma drugs that acts on the conventional outflow pathway. An increasing number of nitric oxide donors have been developed for glaucoma and ocular hypertension treatment. Here, we will review how NO lowers IOP and the types of nitric oxide donors that have been developed. And a brief analysis of the advantages and challenges associated with the application will be made. The literature used in this review is based on Pubmed database search using 'nitric oxide' and 'glaucoma' as key words.

Keywords: glaucoma; conventional outflow system; intraocular pressure; NO donors

\section{Introduction}

Glaucoma, one of the leading causes of irreversible blindness worldwide, refers to a group of diseases characterized by damage of the optic nerve and visual loss. Primary open angle glaucoma (POAG) is estimated to affect 111.8 million people by 2040 [1]. Intraocular pressure (IOP) elevation is a strong risk factor of POAG [2,3]. Therefore, research has been focused on better understanding the mechanism which is responsible for homeostatic regulation of aqueous humor outflow [4,5].

Since nitric oxide (NO) was discovered as a small gas signaling molecule mediating endothelial cell relaxation in 1987, it has been studied as a method of intervention for various diseases $[6,7]$. The mechanism by which NO lowers IOP includes the reduction of aqueous humor production [6,7], the increase of Schlemm's canal (SC) endothelial cell permeability and the relaxation of trabecular meshwork (TM) cells $[8,9]$. The latter two effects can be boiled down to the increase of conventional outflow facility. The elucidation of these mechanisms provides the theoretical basis for the use of NO donors in the treatment of ocular hypertension.

A large amount of NO donors including conventional standalone NO donors, combination NO donors and NO donating nanomedicine have been proven effective in IOP lowering [5,10-21]. Combination therapies can have synergistic effect on IOP lowering, such as NO-donating prostaglandins, NO donating $\beta$-blockers, NO donating carbonic anhydrase inhibitor and the dual NO donor deliver system [22]. NO donor loaded nanoparticles improved the therapeutic effect and action duration of the conventional NO donor [20-22]. $\beta$-gal-NONOate aims to precisely deliver NO in a conventional outflow system [23].

In this review, the mechanism of NO in regulating IOP and the application of NO donor for the treatment of glaucoma and ocular hypertension will be introduced. 


\section{IOP Regulation in Physiological and Pathological Conditions}

To understand how NO donors reduce IOP, it is important to know the mechanism of IOP regulation. Increased resistance to outflow through the TM and SC in the conventional outflow pathway leads to elevated IOP, which may distend the optic nerve head and damage RGC axons at the level of the lamina cribrosa [4,24]. This eventually leads to vision loss and blindness. IOP, which is determined by equilibrium in aqueous humor production and outflow through the conventional pathway and non-conventional system, is the only quantifiable risk factor for glaucoma $[4,24]$. The conventional outflow system consists concretely of the TM, the endothelial of SC, the juxtacanalicular connective tissue, the aqueous veins and the collecting channels. It provides pressure-dependent dynamic aqueous humor outflow $[25,26]$. The unconventional uveoscleral pathway is denominated a pressure-independent pathway. In physiological conditions, the aqueous formation and outflow is under homeostatic regulations [26]. However, if malfunction occurs in the conventional outflow system, the IOP elevates.

Dysfunction of conventional outflow system can be caused by multiple factors, including oxidative stress, cell autophagy, TM stiffness and genetic and environmental factors [3,26-32]. Evidence from previous research depicted a close correlation between human trabecular meshwork (HTM) damage by oxidative damage and elevated IOP in POAG patients [33]. Based on our data from angular aqueous plexus endothelial cells (AAP), which were isolated from porcine eyes and are equivalent to $\mathrm{SC}$ endothelial cells in human [34], chronic oxidative stress impacted on AAP cell barrier function by upregulating cytoskeleton and adhesion proteins [31]. Hyperoxic conditions were reported to contribute lysosomal activity impairment in the porcine TM cells, along with increased autophagic vacuole content [35]. Recently, autophagy in the conventional outflow system was shown to affect IOP $[29,36]$. The up-regulation of autophagosome-associated LC3 and p62, down-regulation of LAMP1 may have caused IOP elevation in DBA/2J mice through autophagic flux diminishment and the failure of the formation of autolysosomes in TM cells [36]. Increased stiffness of the TM may lead to increased conventional aqueous humor outflow resistance and IOP elevation [27,37-39]. TM stiffness depends on the interaction between the ECM and the resident TM cells $[27,40]$. Several factors, including senescence, TGF- $\beta 2$, cytoskeletal disrupting agents, ROCK inhibitors, ocular corticosteroids and NO had been identified to affect TM stiffness [27,40-43].

\section{NO and IOP Regulation}

NO is produced by three isoforms of NO synthase namely nNOS, iNOS and eNOS by the conversion of L-arginine and molecular oxygen to L-citrulline. This process require several cofactors such as reduced nicotinamide-adenine-dinucleotide phosphate (NADPH), flavin adenine dinucleotide (FAD), flavin mononucleotide (FMN), and (6R5,6,7,8-tetrahydrobiopterin $\left(\mathrm{BH}_{4}\right)$ [44-47]. In humans, eNOS expression was found in SC endothelial cells, ciliary body endothelium, TM and the ciliary muscle within the uveoscleral pathway $[44,48-50]$. nNOS is expression ciliary non-pigmented epithelium in human [51] and ciliary process epithelium in rat $[52,53]$. iNOS is expressed in the retina, retinal pigmented epithelium and outflow tissues [54,55]. NO bioavailability was connected with intake of nitrate salts [56].

Regulated by the increase of calcium-induced complex of calcium/calmodulin, nNOS and eNOS usually synthesized only a small quantity of $\mathrm{NO}$ and then played a role via $\mathrm{NO} / \mathrm{sGC} / \mathrm{cGMP}$ pathway or via S-nitrosylation modification for proteins [12-14]. The former pathway was closely related to IOP lowering; the latter may result in inflammation, apoptosis and cytotoxicity $[44,57,58]$. iNOS-induced NO production will also be accompanied by an inflammatory state and cause a large amount of continuous release of nitric oxide in a calcium-independent way, which in turn exacerbates the inflammation through the formation of ONOO- (peroxynitrite) [59-61]. iNOS activation and nitrotyrosine formation correlated with visual loss in in glaucoma patients [54,62]. 
NO relaxes TM cells and makes SC cells more permeable [44,63-70]. The mechanism by which NO regulates IOP is illustrated in Figure 1. The IOP lowering function of NO is primarily mediated by the NO-cGMP pathway [71-74]. Experiment in rabbits has shown that both NO donors and the second messenger derivative (8-Br-cGMP) increased aqueous humor outflow facility dramatically [74]. An increased amount of evidence indicated the indispensable role of enzyme soluble guanylyl cyclase (sGC) in the process of NO-induced IOP lowering [75,76]. In GC-1 knockout mice, NO had little effect on IOP. GC-1 knockout and sGC $\alpha 1$ knockout mice showed impaired conventional outflow, sGC stimulator IWP-953 increased outflow facility [75-77].

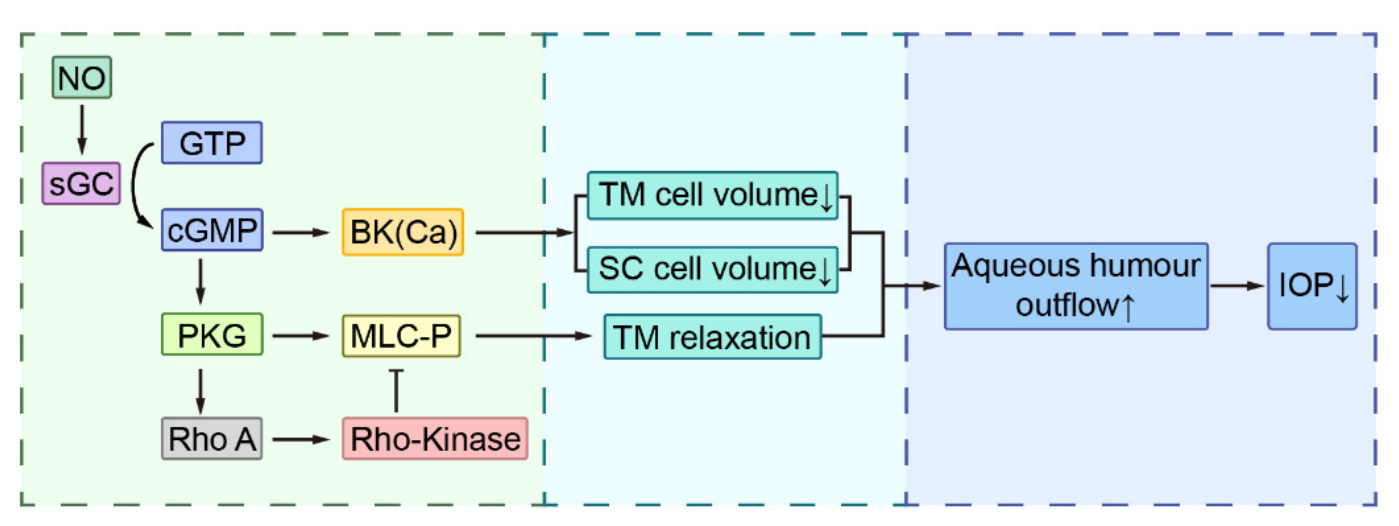

Figure 1. The mechanism of nitric oxide lowering intraocular pressure. TM, Trabecular Meshwork; SC, Schlemm's canal; sGC, soluble guanylyl cyclase; IOP, intraocular pressure; PKG, protein kinase G; MLCP, myosin light chain phosphatase.

TM and SC cell volumes were negatively correlated with outflow facility $[64,68,78]$. A study, performed in human SC cells, showed increased cell volume after L-NAME (NOS inhibitor) exposure. In contrast, NO donors DETA-NO and sodium nitroprusside (SNP) decreased cell volume in TM and SC cells [68,78]. Furthermore, in both TM and SC cell, BKCa channel activation was involved in NO-induced cell volume decrease and facility increase, which could be prevented by sGC inhibitor and IBTX, a BKCa channel inhibitor $[68,78]$.

\section{Nitric Oxide-Donating Drugs for IOP Lowering}

With the invention and application of multiple NO-donating drugs, great progress has been made for NO donors in ocular hypertension treatment (Table 1).

\subsection{Nitric Oxide-Donating Prostaglandins Analogues}

Prostaglandins exhibit a wide range of physiological functions including smooth muscle regulation through interacting with its receptors [5,79]. There are nine PG receptors distributed in both the plasma membrane and nuclear envelope. Among them, FP and EP1-4 were expressed mainly in the uveoscleral tissue in the eye $[5,80]$. Prostaglandin F2 $\alpha$ decreased IOP via FP and EP receptors stimulation, ciliary body (CB) relaxation and pressure-independent outflow increase [11]. Since latanoprost, the first PGF2 $\alpha$ analogue, was approved by the FDA for open-angle glaucoma and ocular hypertension treatment in 1996, the use of prostaglandin analogues began to unfold, they offered one of the best IOP lowering effect for glaucoma patients. [11,12]. Prostaglandin analogues reduced IOP by inducing ECM remodeling in the sclera and ciliary muscle. Once FP receptors was activated, stimulation induced metalloproteinase (MMP) enzymes secretion which including MMP1 and MMP9. The MMPs worked by dissolving collagenase and increasing the outflow rate of aqueous humor by the pressure-independent pathway. On the other hand, endogenous prostaglandins synthesis induced by PLA2 stimulation also contributed to the ECM remodeling $[5,81,82]$. The PG analogues have also been reported to have better 
control of diurnal IOP compared with the nocturnal IOP, which might be due to the impact from nightly physiological fluctuations on the uveoscleral outflow [83].

Table 1. Classifications of NO-donating drugs.

\begin{tabular}{|c|c|c|}
\hline NO-Donating Drugs & & $\begin{array}{l}\text { Underlying Mechanisms } \\
\text { Involving IOP Lowering }\end{array}$ \\
\hline \multirow{2}{*}{ NO-donating Prostaglandins } & LBN $[81,82]$ & $\begin{array}{l}\text { ECM digestion, sGC } \\
\text { stimulation TM relaxation }\end{array}$ \\
\hline & NCX 470 [84] & $\begin{array}{l}\text { PGF2a and NO/cGMP } \\
\text { pathways activation }\end{array}$ \\
\hline NO donating CAIs & NCX 274, NCX 278 [19] & $\begin{array}{l}\text { carbonic anhydrase type-II } \\
\text { isozyme inhibition, } \\
\text { NO/sGC/cGMP pathway } \\
\text { stimulation }\end{array}$ \\
\hline \multirow{2}{*}{$\begin{array}{l}\text { Nano-materials } \\
\text { based NO donors }\end{array}$} & PEG-PAspTETA-SNO [20] & $\begin{array}{l}\text { concentrated endogenous } \\
\text { GSH-triggered NO release }\end{array}$ \\
\hline & SNP@MSNs delivery [21] & $\begin{array}{l}\text { NO-cGMP pathway } \\
\text { stimulation }\end{array}$ \\
\hline \multirow[b]{2}{*}{ Other kinds of NO donors } & Furoxan derivatives [85] & $\begin{array}{l}\text { NO-cGMP pathway } \\
\text { stimulation }\end{array}$ \\
\hline & $\beta$-gal-NONOate [23] & $\begin{array}{l}\text { NO release via } \\
\beta \text {-gal-NONOate enzymatic } \\
\text { biocatalysis }\end{array}$ \\
\hline
\end{tabular}

In contrast to PG analogues, the modified PGs, NO-donating PGF2 $\alpha$ analogues, including latanoprostene bunod (LBN) and NCX 470 showed better IOP lowering effects. They induced both uveoscleral outflow increase by FP receptor stimulation and conventional outflow increase by $\mathrm{NO} / \mathrm{sGC} / \mathrm{cGMP}$ activation $[84,86,87]$. Vyzulta, a $0.024 \%$ latanoprostene bunod eye drop synthesized by Nicox, has been approved by the FDA in patients with POAG and ocular hypertension for IOP reduction [5]. In general, the IOP lowering was achieve in two steps. First, under the action of esterase, LBN was divided into two partsLA (latanoprost acid) and BDMN (butanediol mononitrate)— the former improved aqueous humour outflow facility via MMP secretion induced by FP receptor activation. Then the butanediol mononitrate was metabolized to $\mathrm{NO}$ along with 1,4-butanediol, a byproduct $[81,82]$. In three animal models, including the ocular hypertensive rabbits induced by hypertonic saline, the glaucomatous ocular hypertensive dogs and the laser-induced ocular hypertensive, BOL-303259-X (also called as PF-3187207 or NCX 116) showed more significant effects in IOP reduction than latanoprost [67].

Clinical trials on the safety, tolerability and IOP lowering effect of latanoprostene Bunod (LBN) have been reported. In the phase 1 study, an open-label KRONUS clinical trial, 24 Japanese adult male subjects were selected according to the required standards of the experiment, and then the baseline of IOP was measured. After $0.024 \% \mathrm{LBN}$ administration once a night for up to 14 days, the IOP was measured again and the effect of the medication on the subject was evaluated. The results showed that, compared with the baseline value, the IOP of the study group was significantly reduced. In this study, the common adverse reactions were conjunctival hyperemia and punctate keratitis [88]. In the phase 2 study, a dose-ranging study (VOYAGER) was conducted among 413 subjects with ocular hypertension (OHT) or open angle glaucoma (OAG), aiming to find the most suitable concentration of LBN for lowering IOP by comparing different concentrations of LBN and $0.005 \%$ latanoprost. Regarding the effect of IOP lowering, the $0.024 \%$ dose LBN (decreased 
by 34 percent) showed significantly better than $0.005 \%$ latanoprost did (30 percent). The results demonstrated an additional IOP lowering effect of LBN compared with latanoprost acid (LA) [89]. Another phase 2 trial (CONSTELLATION), among the twenty-four primary open-angle glaucoma and ocular hypertension subjects who participated in the experiment, latanoprostene bunod $0.024 \%$ solution showed better night-time IOP lowering effect than timolol maleate $0.5 \%$ solution [90]. In phase 3 , clinical trials APOLLO and LUNAR were carried out among the subjects with ocular hypertension (OHT) or open angle glaucoma (OAG) in Europe and North America in order to further explore the safety and effectiveness of $0.024 \%$ LBN $[91,92]$. In the studies above, the timolol $0.5 \%$ treatment group was regarded as the control group. Both studies showed that after three months of administration, LBN $0.024 \%$ exhibited more significant effect in terms of lowering IOP than timolol $0.5 \%$.

NCX 470, a NO donating PGF2 $\alpha$ analogue molecule, was synthesized by transforming 15 hydroxyl within bimatoprost into 6-(nitrooxy) hexanoic acid via esterification [84]. In ocular hypertension and glaucoma animal models, NCX 470 showed more effective IOP reduction than bimatoprost. In addition, in both ONT-dogs (ocular normotensive dogs) and OHT-monkeys (ocular hypertensive monkeys), NCX 470 0.042\% reduced IOP more than equimolar bimatoprost (0.03\%) [84]. However, clinical results of NCX470 is to be released.

\subsection{Nitric Oxide-Donating Carbonic Anhydrase Inhibitor}

The carbonic anhydrase isoforms were expressed in the ciliary body. The isoforms CA I, II, IV and XII, are related to the aqueous humor secretion [93]. Carbonic anhydrase inhibitors (CAIs) were reported to lower IOP by up to $25-30 \%$ via inhibiting isozymes in the ciliary body, such as CA II and CA XII $[17,18]$. Systemic intake of the CAIs, such as acetazolamide, methazolamide and ethoxzolamidelowered IOP significantly. However, due to the ubiquitous distribution of the carbonic anhydrase in the body, systemic side effects, such as metabolic acidosis, weight loss and paresthesia at the extremities have been also frequently reported [94-96]. Despite the systemic side effects, CAIs have good application prospects for refractory glaucoma [97]. The good news is that newly developed CAIs have better water solubility and better corneal penetration, such as dorzolamide and brinzolamide, which made it possible to use topical drugs on the ocular surface and have fewer side effects than drugs administered systemically $[17,18,96]$. However, dorzolamide still has side effects such as depression [98], nephrolithiasis [99], and allergic contact dermatitis (ACD) [100].

Several bi-functional compounds with a NO-donatng moiety bound to a dorzolamide scaffold demonstrated NO mediated effects in the vasculature [19]. Among them NCX 274 and NCX 278 showed ocular hypertensive effects in normotensive rabbits. NCX 274 consisted of a nitrate ester carried by a nitric oxide-donor linker with amino group of dorzolamide through amides, whereas NCX 278 was coupled with carbamates. NCX 274 showed a more powerful IOP lowering effect of NCX 274 than dorzolamide.

\subsection{Nano-Material Based NO Donors}

In contrast to classic NO donors, an increasing number of nano-material based NO donors have emerged aiming to overcome some of the inherent problems of NO donors, such as instability and a short half-life [101,102]. Nanoparticles based NO donors include silica nanoparticles, metal oxide nanoparticles, polymer coated metal nanoparticles and other kinds of nanomaterials (such as dendrimers, micelles) [103]. In additional to IOP lowering [35], it has a wide range of applications including wound healing [104,105], antimicrobial [106,107], cardiovascular diseases treatment [108-111], erectile dysfunction improvement [112], relieving liver fibrosis [113].

For silica nanoparticles, mesoporous silica nanoparticles (MSNs) and xxx were used as carrier for NO donors [21,22]. Compared with nitroprusside (SNP) solution, the SNP@MSN system exhibited more efficacious and long lasting effect in IOP lowering [21]. With 1/40 dose, SNP@MSN increased IOP lowering effect from 3 hours to 48 hours. For hollow 
mesoporous organosilica (HOS) nanocapsules, it was biodegradable and can achieve trans-corneal co-delivery of hydrophobic NO donor JS-K (JR) and hydrophilic NO donor L-Arginine (LO) to the target tissues inside the eye [22]. HOS- $\mathrm{J}_{\mathrm{R}} \mathrm{L}_{\mathrm{O}}$ was endogenous stimuli-responsive and was reduced and oxidized by ascorbic acid and catalysis of eNOS to release a large amount of NO molecules to lower IOP. It successfully treated ocular hypertension in three animal models. HOS- $\mathrm{J}_{R} \mathrm{~L}_{\mathrm{O}}$ seemed to be a versatile, non-invasive, and efficacious treatment paradigm for precision glaucoma therapy.

Macromolecule composite NO carriers have been also developed to release NO. In $\beta$-gal-NONOate-loaded liposomes coated by $\beta$-galactosidase-loaded polymer, NO release was accomplished by the catalytic role $\beta$-galactosidase played in the catalysis of $\beta$-gal-NONOate. Results from C57BL/ 6 mice showed the conventional outflow facility within the $\beta$-gal-NONOate-loaded liposomes treated group, which, under the effect of $\beta$-galactosidase, increased by $84 \%$ compared with the vehicle-treated group [23]. This invention gave a good example for NO delivery platform design. Recently, a new polymer combining super cation with GSH (glutathione) responsiveness (PEG-PAspTETA-SNO) was developed as carrier for NO [20]. PEG-PAspTETA-SNO showed more effective corneal penetration and significant IOP lowering effect in both C57BL/6 mice and eNOS knockout mice than the PEGPAspHMDA-SNO control group. Results from AAP cells indicated better uptake for PEGPAspTETA-SNO-RhoB (Rhodamine B labeled polymers) than PEGPAspHMDA-SNO-RhoB control group. The endocytosis effect of PEG-PAspTETA-SNORhoB was inhibited by caveolae inhibitor $\mathrm{m} \beta-\mathrm{CD}$, which indicated caveolae-Golgi may play a vital role in the PEG-PAspTETA-SNO induced endocytosis.

\subsection{Other Kinds of NO Donors}

The NO release from furoxan can be triggered by mercaptan cofactor. The function of substituents on the ring varied with its arrangement position. The third group of substituents is in charge of the total amount release of NO, and the fourth one is responsible for the balance of hydrophilic-lipophilic [85]. Blangetti et al. developed a big array of furoxan derivatives based on the basis above, the IOP lowering effects of which were tested in a transient ocular hypertensive rabbit model (tOHT). Some compounds showed similar IOP lowering effect to timolol after an hour of dosing. The study concluded that it was not the amount of NO released but the hydrophilic-lipophilic balance that determined the IOP lowering effects of such kinds of furoxan derivatives.

\section{Challenges Associated with NO Donors}

Although NO donor Vyzulta has been approved by the FDA for the treatment of glaucoma and ocular hypertension, some problems remain to be solved. Nitrate tolerance or organic nitrates' invalidation occurred among coupled NO donors during continuous therapy [114-116]. The formation of s-nitrosothiols and nitration is the product of the reaction between NO and protein [117], and it is also a potential factor that causes damage to the conventional outflow pathway and ocular hypertension [118]. A recent study showed that a single dose of SNP@MSNs (NO donor) in wild-type mouse eyes can lower the IOP (up to $48 \mathrm{~h}$ ), but continuous use of SNP@MSNs caused an increasing IOP (from the sixth day on). However, co-application of SNP@MSNs with MnTMPyP (antioxidant) could not only prevent IOP increase, but also increase the magnitude of IOP lowering [118]. This experiment revealed the problem of peroxynitrite (ONOO-) accumulation caused by continuous release of NO. Further research in this direction will help avoid side effects and improve the efficacy of NO donors.

\section{Conclusions}

NO donors have made great progress in the treatment of various diseases, especially in glaucoma and ocular hypertension. Future development of NO donors should focus on effective topical delivery (as eye drops), longer duration of action and minimizing long term side effects. In order to achieve these goals, it is important to continue exploring in 
designing and synthesizing better NO donors. New attempts will help to develop better and more treatment option for the well-being of glaucoma patients.

Author Contributions: B.H. wrote the initial draft of the manuscript under the guidance of Y.L. and X.S., Y.L., L.L. and M.S. proof read the manuscript. All authors have read and agreed to the published version of the manuscript.

Funding: This authors were supported by National Natural Science Foundation China (82070959, 81790641, 82030027), Shanghai Natural Science Fund General Project (21ZR1411500), Individualized support project for original scientific research of Fudan University (IDF158017/005), the International Science and Technology Cooperation Program of China (No.2015DFA31340), BrightFocus Foundation (G2018112).

Conflicts of Interest: The authors declare no conflict of interest.

\section{Abbreviations}

NO, nitric oxide; IOP, intraocular pressure; LBN, latanoprostene bunod; ECM, extracellular matrix; sGC, soluble guanylate cyclase.

\section{References}

1. Tham, Y.C.; Li, X.; Wong, T.Y.; Quigley, H.A.; Aung, T.; Cheng, C.Y. Global prevalence of glaucoma and projections of glaucoma burden through 2040: A systematic review and meta-analysis. Ophthalmology 2014, 121, 2081-2090. [CrossRef] [PubMed]

2. Leske, M.C.; Heijl, A.; Hyman, L.; Bengtsson, B.; Dong, L.; Yang, Z. Predictors of Long-term Progression in the Early Manifest Glaucoma Trial. Ophthalmol. 2007, 114, 1965-1972. [CrossRef]

3. Stamer, W.D.; Acott, T.S. Current understanding of conventional outflow dysfunction in glaucoma. Curr. Opin. Ophthalmol. 2012, 23, 135-143. [CrossRef] [PubMed]

4. Aliancy, J.; Stamer, W.D.; Wirostko, B. A Review of Nitric Oxide for the Treatment of Glaucomatous Disease. Ophthalmol. Ther. 2017, 6, 221-232. [CrossRef] [PubMed]

5. Impagnatiello, F.; Bastia, E.; Almirante, N.; Brambilla, S.; Duquesroix, B.; Kothe, A.C.; Bergamini, M.V.W. Prostaglandin analogues and nitric oxide contribution in the treatment of ocular hypertension and glaucoma. Br. J. Pharmacol. 2019, 176, 1079-1089. [CrossRef]

6. Shahidullah, M.; Yap, M.; To, C.-H. Cyclic GMP, sodium nitroprusside and sodium azide reduce aqueous humour formation in the isolated arterially perfused pig eye. Br. J. Pharmacol. 2005, 145, 84-92. [CrossRef]

7. Shahidullah, M.; Delamere, N. NO donors inhibit Na,K-ATPase activity by a protein kinase G-dependent mechanism in the nonpigmented ciliary epithelium of the porcine eye. Br. J. Pharmacol. 2006, 148, 871-880. [CrossRef]

8. Cavet, M.E.; Vittitow, J.L.; Impagnatiello, F.; Ongini, E.; Bastia, E. Nitric Oxide (NO): An Emerging Target for the Treatment of Glaucoma. Investig. Opthalmology Vis. Sci. 2014, 55, 5005-5015. [CrossRef]

9. Wiederholt, M.; Thieme, H.; Stumpff, F. The regulation of trabecular meshwork and ciliary muscle contractility. Prog. Retin. Eye Res. 2000, 19, 271-295. [CrossRef]

10. Lei, Y.; Zhang, X.; Song, M.; Wu, J.-H.; Sun, X. Aqueous Humor Outflow Physiology in NOS3 Knockout Mice. Investig. Opthalmology Vis. Sci. 2015, 56, 4891-4898. [CrossRef]

11. Winkler, N.; Fautsch, M.P. Effects of Prostaglandin Analogues on Aqueous Humor Outflow Pathways. J. Ocul. Pharmacol. Ther. 2014, 30, 102-109. [CrossRef]

12. Alm, A.; Nilsson, S.F. Uveoscleral outflow-A review. Exp. Eye Res. 2009, 88, 760-768. [CrossRef] [PubMed]

13. Orzalesi, N.; Rossetti, L.; Invernizzi, T.; Bottoli, A.; Autelitano, A. Effect of timolol, latanoprost, and dorzolamide on circadian IOP in glaucoma or ocular hypertension. Investig. Ophthalmol. Vis. Sci. 2000, 41, 2566-2573.

14. Lorenz, K.; Pfeiffer, N. Efficacy and safety of tafluprost $0.0015 \%$ and timolol maleate $0.5 \%$ fixed combination in patients with ocular hypertension or open-angle glaucoma. Expert Opin. Pharmacother. 2014, 15, 2255-2262. [CrossRef] [PubMed]

15. Kanno, M.; Araie, M.; Koibuchi, H.; Masuda, K. Effects of topical nipradilol, a beta blocking agent with alpha blocking and nitroglycerin-like activities, on intraocular pressure and aqueous dynamics in humans. Br. J. Ophthalmol. 2000, 84, 293-299. [CrossRef] [PubMed]

16. Kanno, M.; Araie, M.; Tomita, K.; Sawanobori, K. Effects of topical nipradilol, a beta-blocking agent with alpha-blocking and nitroglycerin-like activities, on aqueous humor dynamics and fundus circulation. Investig. Ophthalmol. Vis. Sci. 1998, 39, 736-743.

17. Supuran, C.T. Carbonic anhydrases: Novel therapeutic applications for inhibitors and activators. Nat. Rev. Drug Discov. 2008, 7, 168-181. [CrossRef]

18. Mincione, F.; Starnotti, M.; Masini, E.; Bacciottini, L.; Scrivanti, C.; Casini, A.; Vullo, D.; Scozzafava, A.; Supuran, C.T. Carbonic anhydrase inhibitors: Design of thioureido sulfonamides with potent isozyme II and XII inhibitory properties and intraocular pressure lowering activity in a rabbit model of glaucoma. Bioorganic Med. Chem. Lett. 2005, 15, 3821-3827. [CrossRef] 
19. Steele, R.M.; Benedini, F.; Biondi, S.; Borghi, V.; Carzaniga, L.; Impagnatiello, F.; Miglietta, D.; Chong, W.K.; Rajapakse, R.; Cecchi, A.; et al. Nitric oxide-donating carbonic anhydrase inhibitors for the treatment of open-angle glaucoma. Bioorganic Med. Chem. Lett. 2009, 19, 6565-6570. [CrossRef]

20. Jia, F.; Li, L.; Fang, Y.; Song, M.; Man, J.; Jin, Q.; Lei, Y.; Ji, J. Macromolecular Platform with Super-Cation Enhanced Trans-Cornea Infiltration for Noninvasive Nitric Oxide Delivery in Ocular Therapy. ACS Nano 2020, 14, 16929-16938. [CrossRef]

21. Hu, C.; Sun, J.; Zhang, Y.; Chen, J.; Lei, Y.; Sun, X.; Deng, Y. Local Delivery and Sustained-Release of Nitric Oxide Donor Loaded in Mesoporous Silica Particles for Efficient Treatment of Primary Open-Angle Glaucoma. Adv. Heal. Mater. 2018, 7, e1801047. [CrossRef] [PubMed]

22. Fan, W.; Song, M.; Li, L.; Niu, L.; Chen, Y.; Han, B.; Sun, X.; Yang, Z.; Lei, Y.; Chen, X. Endogenous dual stimuli-activated NO generation in the conventional outflow pathway for precision glaucoma therapy. Biomaterials 2021, 277, 121074. [CrossRef] [PubMed]

23. Chandrawati, R.; Chang, J.Y.; Reina-Torres, E.; Jumeaux, C.; Sherwood, J.M.; Stamer, W.D.; Zelikin, A.N.; Overby, D.R.; Stevens, M.M. Localized and Controlled Delivery of Nitric Oxide to the Conventional Outflow Pathway via Enzyme Biocatalysis: Toward Therapy for Glaucoma. Adv. Mater. 2017, 29, 1604932. [CrossRef] [PubMed]

24. Heijl, A.; Bengtsson, B.; Hyman, L.; Leske, M.C. Natural History of Open-Angle Glaucoma. Ophthalmology 2009, 116, 2271-2276. [CrossRef] [PubMed]

25. Tamm, E.R. The trabecular meshwork outflow pathways: Structural and functional aspects. Exp. Eye Res. 2009, 88, 648-655. [CrossRef]

26. Andrés-Guerrero, V.; Feijoo, J.G.; Konstas, A.G. Targeting Schlemm's Canal in the Medical Therapy of Glaucoma: Current and Future Considerations. Adv. Ther. 2017, 34, 1049-1069. [CrossRef]

27. Wang, K.; Read, A.T.; Sulchek, T.; Ethier, C.R. Trabecular meshwork stiffness in glaucoma. Exp. Eye Res. 2017, 158, 3-12. [CrossRef]

28. Ster, A.M.; Popp, R.A.; Petrisor, F.M.; Stan, C.; Pop, V.I. The Role of Oxidative Stress and Vascular Insufficiency in Primary Open Angle Glaucoma. Clujul Med. 2014, 87, 143.

29. Nettesheim, A.; Dixon, A.; Shim, M.S.; Coyne, A.; Walsh, M.; Liton, P.B. Autophagy in the Aging and Experimental Ocular Hypertensive Mouse Model. Investig. Opthalmol. Vis. Sci. 2020, 61, 31. [CrossRef]

30. Lei, Y.; Stamer, W.D.; Wu, J.; Sun, X. Cell Senescence Reduced the Mechanotransduction Sensitivity of Porcine Angular Aqueous Plexus Cells to Elevation of Pressure. Investig. Opthalmol. Vis. Sci. 2014, 55, 2324-2328. [CrossRef]

31. Lei, Y.; Stamer, W.D.; Wu, J.-H.; Sun, X. Oxidative Stress Impact on Barrier Function of Porcine Angular Aqueous Plexus Cell Monolayers. Investig. Opthalmol. Vis. Sci. 2013, 54, 4827-4835. [CrossRef]

32. Niu, L.; Li, L.; Xing, C.; Luo, B.; Hu, C.; Song, M.; Niu, J.; Ruan, Y.; Sun, X.; Lei, Y. Airborne particulate matter (PM2.5) triggers cornea inflammation and pyroptosis via NLRP3 activation. Ecotoxicol. Environ. Saf. 2021, 207, 111306. [CrossRef]

33. Saccà, S.C.; Pascotto, A.; Camicione, P.; Capris, P.; Izzotti, A. Oxidative DNA damage in the human trabecular mesh-work: Clinical correlation in patients with primary open-angle glaucoma. Arch. Ophthalmol. 2005, 123, 458-463. [CrossRef] [PubMed]

34. Lei, Y.; Overby, D.R.; Read, A.T.; Stamer, W.D.; Ethier, C.R. A new method for selection of angular aqueous plexus cells from porcine eyes: A model for Schlemm's canal endothelium. Investig. Ophthalmol. Vis. Sci. 2010, 51, 5744-5750. [CrossRef] [PubMed]

35. Liton, P.B.; Lin, Y.; Luna, C.; Li, G.; Gonzalez, P.; Epstein, D.L. Cultured Porcine Trabecular Meshwork Cells Display Altered Lysosomal Function When Subjected to Chronic Oxidative Stress. Investig. Opthalmol. Vis. Sci. 2008, 49, 3961-3969. [CrossRef]

36. Hirt, J.; Porter, K.; Dixon, A.; McKinnon, S.; Liton, P.B. Contribution of autophagy to ocular hypertension and neurodegeneration in the DBA/2J spontaneous glaucoma mouse model. Cell Death Discov. 2018, 4, 14. [CrossRef] [PubMed]

37. Last, J.A.; Pan, T.; Ding, Y.; Reilly, C.M.; Keller, K.; Acott, T.S.; Fautsch, M.P.; Murphy, C.J.; Russell, P. Elastic Modulus Determination of Normal and Glaucomatous Human Trabecular Meshwork. Investig. Opthalmol. Vis. Sci. 2011, 52, 2147-2152. [CrossRef]

38. Camras, L.J.; Stamer, W.D.; Epstein, D.; Gonzalez, P.; Yuan, F. Differential Effects of Trabecular Meshwork Stiffness on Outflow Facility in Normal Human and Porcine Eyes. Investig. Opthalmol. Vis. Sci. 2012, 53, 5242-5250. [CrossRef] [PubMed]

39. Wang, K.; Johnstone, M.A.; Xin, C.; Song, S.; Padilla, S.; Vranka, J.A.; Acott, T.S.; Zhou, K.; Schwaner, S.A.; Wang, R.; et al. Estimating Human Trabecular Meshwork Stiffness by Numerical Modeling and Advanced OCT Imaging. Investig. Opthalmol. Vis. Sci. 2017, 58, 4809-4817. [CrossRef]

40. Fuchshofer, R.; Tamm, E.R. The role of TGF- $\beta$ in the pathogenesis of primary open-angle glaucoma. Z. Zellforsch. Mikrosk. Anat. 2011, 347, 279-290. [CrossRef]

41. Ethier, C.R.; Read, A.T.; Chan, D.W.-H. Effects of Latrunculin-B on Outflow Facility and Trabecular Meshwork Structure in Human Eyes. Investig. Opthalmol. Vis. Sci. 2006, 47, 1991-1998. [CrossRef]

42. Tian, B.; Gabelt, B.T.; A Peterson, J.; A Kiland, J.; Kaufman, P.L. H-7 increases trabecular facility and facility after ciliary muscle disinsertion in monkeys. Investig. Ophthalmol. Vis. Sci. 1999, 40, 239-242.

43. McKee, C.T.; Wood, J.A.; Shah, N.M.; Fischer, M.E.; Reilly, C.M.; Murphy, C.J.; Russell, P. The effect of biophysical attributes of the ocular trabecular meshwork associated with glaucoma on the cell response to therapeutic agents. Biomaterials 2011, 32, $2417-2423$. [CrossRef]

44. Wareham, L.K.; Buys, E.S.; Sappington, R.M. The nitric oxide-guanylate cyclase pathway and glaucoma. Nitric Oxide 2018, 77, 75-87. [CrossRef] 
45. Kamm, A.; Przychodzen, P.; Kuban-Jankowska, A.; Jacewicz, D.; Dabrowska, A.M.; Nussberger, S.; Wozniak, M.; GorskaPonikowska, M. Nitric oxide and its derivatives in the cancer battlefield. Nitric Oxide 2019, 93, 102-114. [CrossRef]

46. Palmer, R.M.J.; Ashton, D.S.; Moncada, S. Vascular endothelial cells synthesize nitric oxide from L-arginine. Nat. Cell Biol. 1988, 333, 664-666. [CrossRef]

47. Palmer, R.M.; Moncada, S. A novel citrulline-forming enzyme implicated in the formation of nitric oxide by vascular endothelial cells. Biochem. Biophys. Res. Commun. 1989, 158, 348-352. [CrossRef]

48. A Nathanson, J.; McKee, M. Identification of an extensive system of nitric oxide-producing cells in the ciliary muscle and outflow pathway of the human eye. Investig. Ophthalmol. Vis. Sci. 1995, 36, 1765-1773.

49. Becquet, F.; Courtois, Y.; Goureau, O. Nitric oxide in the eye: Multifaceted roles and diverse outcomes. Surv. Ophthalmol. 1997, 42, 71-82. [CrossRef]

50. Chang, J.Y.; Stamer, W.D.; Bertrand, J.; Read, A.T.; Marando, C.; Ethier, C.R.; Overby, D.R. Role of nitric oxide in murine conventional outflow physiology. Am. J. Physiol. Physiol. 2015, 309, C205-C214. [CrossRef] [PubMed]

51. Knowles, R.G.; Palacios, M.; Palmer, R.M.; Moncada, S. Formation of nitric oxide from L-arginine in the central nervous system: A transduction mechanism for stimulation of the soluble guanylate cyclase. Proc. Natl. Acad. Sci. USA 1989, 86, 5159-5162. [CrossRef]

52. Mergia, E.; Russwurm, M.; Zoidl, G.; Koesling, D. Major occurrence of the new alpha2beta1 isoform of NO-sensitive guanylyl cyclase in brain. Cell Signal. 2003, 15, 189-195. [CrossRef]

53. Francis, S.H.; Busch, J.L.; Corbin, J.D. cGMP-Dependent Protein Kinases and cGMP Phosphodiesterases in Nitric Oxide and cGMP Action. Pharmacol. Rev. 2010, 62, 525-563. [CrossRef]

54. Fernández-Durango, R.; Fernández-Martínez, A.; Feijoo, J.G.; Castillo, A.; De La Casa, J.M.; Bueno, B.G.; Perez-Nievas, B.G.; Fernández-Cruz, A.; Leza, J.C. Expression of Nitrotyrosine and Oxidative Consequences in the Trabecular Meshwork of Patients with Primary Open-Angle Glaucoma. Investig. Opthalmol. Vis. Sci. 2008, 49, 2506-2511. [CrossRef]

55. Sierra, A.; Navascués, J.; Cuadros, M.A.; Calvente, R.; Martín-Oliva, D.; Ferrer-Martín, R.M.; Martín-Estebané, M.; Car-rasco, M.C.; Marín-Teva, J.L. Expression of inducible nitric oxide synthase (iNOS) in microglia of the developing quail retina. PLoS ONE 2014, 9, e106048.

56. Kang, J.H.; Willett, W.C.; Rosner, B.A.; Buys, E.; Wiggs, J.L.; Pasquale, L.R. Association of Dietary Nitrate Intake With Primary Open-Angle Glaucoma: A Prospective Analysis From the Nurses' Health Study and Health Professionals Follow-up Study. JAMA Ophthalmol. 2016, 134, 294-303. [CrossRef]

57. Hara, M.R.; Agrawal, N.; Kim, S.F.; Cascio, M.B.; Fujimuro, M.; Ozeki, Y.; Takahashi, M.; Cheah, J.H.; Tankou, S.K.; Hester, L.D.; et al. S-nitrosylated GAPDH initiates apoptotic cell death by nuclear translocation following Siah1 binding. Nat. Cell Biol. 2005, 7, 665-674. [CrossRef]

58. Handy, D.E.; Loscalzo, J. Nitric oxide and posttranslational modification of the vascular proteome: S-nitrosation of reactive thiols. Arterioscler. Thromb. Vasc. Biol. 2006, 26, 1207-1214. [CrossRef] [PubMed]

59. Pacher, P.; Beckman, J.S.; Liaudet, L. Nitric Oxide and Peroxynitrite in Health and Disease. Physiol. Rev. 2007, 87, 315-424. [CrossRef] [PubMed]

60. Buys, E.S.; Potter, L.R.; Pasquale, L.R.; Ksander, B.R. Regulation of intraocular pressure by soluble and membrane guanylate cyclases and their role in glaucoma. Front. Mol. Neurosci. 2014, 7, 38. [CrossRef] [PubMed]

61. Goureau, O.; Lepoivre, M.; Becquet, F.; Courtois, Y. Differential regulation of inducible nitric oxide synthase by fibroblast growth factors and transforming growth factor beta in bovine retinal pigmented epithelial cells: Inverse correlation with cellular proliferation. Proc. Natl. Acad. Sci. USA 1993, 90, 4276-4280. [CrossRef] [PubMed]

62. Wojnicz, R.; Rokicki, W.; Żaba, M.; Wyględowska-Promieńska, D.; Kabiesz, A.; Reichman-Warmusz, E.; Brzozowa, M.; Majewski, W. Inducible and Endothelial Nitric Synthetase Expression and Nitrotyrosine Accumulation in Iris Vasculature of Patients with Primary Open-Angle Glaucoma: A Pilot Study. Med. Sci. Monit. 2015, 21, 76-81. [CrossRef] [PubMed]

63. Garhöfer, G.; Schmetterer, L. Nitric oxide: A drug target for glaucoma revisited. Drug Discov. Today 2019, 24, 1614-1620. [CrossRef]

64. Ellis, D.Z. Guanylate cyclase activators, cell volume changes and IOP reduction. Cell. Physiol. Biochem. 2011, 28, 1145-1154. [CrossRef]

65. Nathanson, J.A. Direct application of a guanylate cyclase activator lowers intraocular pressure. Eur. J. Pharmacol. 1988, 147, 155-156. [CrossRef]

66. Behar-Cohen, F.F.; Goureau, O.; D’Hermies, F.; Courtois, Y. Decreased intraocular pressure induced by nitric oxide donors is correlated to nitrite production in the rabbit eye. Investig. Ophthalmol. Vis. Sci. 1996, 37, 1711-1715.

67. Krauss, A.H.; Impagnatiello, F.; Toris, C.B.; Gale, D.C.; Prasanna, G.; Borghi, V.; Chiroli, V.; Chong, W.; Carreiro, S.T.; Ongini, E. Ocular hypotensive activity of BOL-303259-X, a nitric oxide donating Prostaglandin F2 $\alpha$ agonist, in preclinical models. Exp. Eye Res. 2011, 93, 250-255. [CrossRef] [PubMed]

68. Dismuke, W.M.; Mbadugha, C.C.; Ellis, D.Z. NO-induced regulation of human trabecular meshwork cell volume and aqueous humor outflow facility involve the BKCa ion channel. Am. J. Physiol. Physiol. 2008, 294, C1378-C1386. [CrossRef]

69. Dismuke, W.M.; Sharif, N.A.; Ellis, D.Z. Human Trabecular Meshwork Cell Volume Decrease by NO-Independent Soluble Guanylate Cyclase Activators YC-1 and BAY-58-2667 Involves the BKCaIon Channel. Investig. Opthalmol. Vis. Sci. 2009, 50, 3353-3359. [CrossRef] 
70. Heyne, G.W.; Kiland, J.A.; Kaufman, P.L.; Gabelt, B.T. Effect of Nitric Oxide on Anterior Segment Physiology in Monkeys. Investig. Opthalmol. Vis. Sci. 2013, 54, 5103-5110. [CrossRef]

71. Kotikoski, H.; Alajuuma, P.; Moilanen, E.; Salmenperä, P.; Oksala, O.; Laippala, P.; Vapaatalo, H. Comparison of Nitric Oxide Donors in Lowering Intraocular Pressure in Rabbits: Role of Cyclic GMP. J. Ocul. Pharmacol. Ther. 2002, 18, 11-23. [CrossRef] [PubMed]

72. Korenfeld, M.S.; Becker, B. Atrial natriuretic peptides. Effects on intraocular pressure, cGMP, and aqueous flow. Investig. Ophthalmol. Vis. Sci. 1989, 30, 2385-2392.

73. Becker, B. Topical 8-bromo-cyclic GMP lowers intraocular pressure in rabbits. Investig. Ophthalmol. Vis. Sci. 1990, 31, 1647-1649.

74. Samuelsson-Almén, M.; Nilsson, S.F.; Mäepea, O.; Bill, A. Effects of atrial natriuretic factor (ANF) on intraocular pressure and aqueous humor flow in the cynomolgus monkey. Exp. Eye Res. 1991, 53, 253-260. [CrossRef]

75. Muenster, S.; Lieb, W.S.; Fabry, G.; Allen, K.N.; Kamat, S.S.; Guy, A.H.; Dordea, A.C.; Teixeira, L.; Tainsh, R.E.; Yu, B.; et al. The Ability of Nitric Oxide to Lower Intraocular Pressure Is Dependent on Guanylyl Cyclase. Investig. Opthalmol. Vis. Sci. 2017, 58, 4826-4835. [CrossRef] [PubMed]

76. Ge, P.; Navarro, I.D.; Kessler, M.M.; Bernier, S.G.; Perl, N.R.; Sarno, R.; Masferrer, J.; Hannig, G.; Stamer, W.D. The Soluble Guanylate Cyclase Stimulator IWP-953 Increases Conventional Outflow Facility in Mouse Eyes. Investig. Opthalmol. Vis. Sci. 2016, 57, 1317-1326. [CrossRef]

77. Ellis, D.Z.; Dismuke, W.M.; Chokshi, B.M. Characterization of Soluble Guanylate Cyclase in NO-Induced Increases in Aqueous Humor Outflow Facility and in the Trabecular Meshwork. Investig. Opthalmol. Vis. Sci. 2009, 50, 1808-1813. [CrossRef]

78. Ellis, D.Z.; Sharif, N.A.; Dismuke, W.M. Endogenous regulation of human Schlemm's canal cell volume by nitric oxide signaling. Investig. Ophthalmol. Vis. Sci. 2010, 51, 5817-5824. [CrossRef]

79. Mao, Y.-J.; Wu, J.-B.; Yang, Z.-Q.; Zhang, Y.-H.; Huang, Z.-J. Nitric oxide donating anti-glaucoma drugs: Advances and prospects. Chin. J. Nat. Med. 2020, 18, 275-283. [CrossRef]

80. Alexander, S.P.; Christopoulos, A.; Davenport, A.P.; Kelly, E.; Marrion, N.V.; Peters, J.A.; Faccenda, E.; Harding, S.D.; Pawson, A.J.; Sharman, J.L.; et al. THE Concise Guide to Pharmacology 2017/18: G protein-coupled receptors. Br. J. Pharmacol. 2017, 174 (Suppl. 1), S17-S129. [CrossRef]

81. A Garcia, G.; Ngai, P.; Mosaed, S.; Lin, K.Y. Critical evaluation of latanoprostene bunod in the treatment of glaucoma. Clin. Ophthalmol. 2016, ume 10, 2035-2050. [CrossRef]

82. Cavet, M.E.; DeCory, H.H. The Role of Nitric Oxide in the Intraocular Pressure Lowering Efficacy of Latanoprostene Bunod: Review of Nonclinical Studies. J. Ocul. Pharmacol. Ther. 2018, 34, 52-60. [CrossRef] [PubMed]

83. Gulati, V.; Fan, S.; Zhao, M.; Maslonka, M.A.; Gangahar, C.; Toris, C.B. Diurnal and Nocturnal Variations in Aqueous Humor Dynamics of Patients with Ocular Hypertension Undergoing Medical Therapy. Arch. Ophthalmol. 2012, 130, 677-684. [CrossRef] [PubMed]

84. Impagnatiello, F.; Toris, C.B.; Batugo, M.; Prasanna, G.; Borghi, V.; Bastia, E.; Ongini, E.; Krauss, A.H.P. Intraocular PressureLowering Activity of NCX 470, a Novel Nitric Oxide-Donating Bimatoprost in Preclinical Models. Investig. Opthalmol. Vis. Sci. 2015, 56, 6558. [CrossRef] [PubMed]

85. Blangetti, M.; Rolando, B.; Chegaev, K.; Guglielmo, S.; Lazzarato, L.; Durante, M.; Masini, E.; Almirante, N.; Bastia, E.; Impagnatiello, F.; et al. New furoxan derivatives for the treatment of ocular hypertension. Bioorganic Med. Chem. Lett. 2017, 27, 479-483. [CrossRef]

86. Cavet, M.E.; Vollmer, T.R.; Harrington, K.L.; VanDerMeid, K.R.; Richardson, M.E. Regulation of Endothelin-1-Induced Trabecular Meshwork Cell Contractility by Latanoprostene Bunod. Investig. Opthalmol. Vis. Sci. 2015, 56, 4108-4116. [CrossRef]

87. Costa, V.P.; Harris, A.; Anderson, D.; Stodtmeister, R.; Cremasco, F.; Kergoat, H.; Lovasik, J.; Stalmans, I.; Zeitz, O.; Lanzl, I.; et al. Ocular perfusion pressure in glaucoma. Acta Ophthalmol. 2014, 92, e252-e266. [CrossRef]

88. Araie, M.; Sforzolini, B.S.; Vittitow, J.; Weinreb, R.N. Evaluation of the Effect of Latanoprostene Bunod Ophthalmic Solution, $0.024 \%$ in Lowering Intraocular Pressure over $24 \mathrm{~h}$ in Healthy Japanese Subjects. Adv. Ther. 2015, 32, 1128-1139. [CrossRef]

89. Weinreb, R.N.; Ong, T.; Sforzolini, B.S.; Vittitow, J.L.; Singh, K.; Kaufman, P.L. A randomised, controlled comparison of latanoprostene bunod and latanoprost $0.005 \%$ in the treatment of ocular hypertension and open angle glaucoma: The VOYAGER study. Br. J. Ophthalmol. 2015, 99, 738-745. [CrossRef]

90. Liu, J.H.; Slight, J.R.; Vittitow, J.L.; Sforzolini, B.S.; Weinreb, R.N. Efficacy of Latanoprostene Bunod 0.024\% Compared with Timolol 0.5\% in Lowering Intraocular Pressure Over 24 Hours. Am. J. Ophthalmol. 2016, 169, 249-257. [CrossRef]

91. Weinreb, R.N.; Scassellati Sforzolini, B.; Vittitow, J.; Liebmann, J. Latanoprostene Bunod 0.024\% versus Timolol Male-ate 0.5\% in Subjects with Open-Angle Glaucoma or Ocular Hypertension: The APOLLO Study. Ophthalmology 2016, 123, 965-973. [CrossRef]

92. Medeiros, F.A.; Martin, K.R.; Peace, J.; Sforzolini, B.S.; Vittitow, J.L.; Weinreb, R.N. Comparison of Latanoprostene Bunod 0.024\% and Timolol Maleate 0.5\% in Open-Angle Glaucoma or Ocular Hypertension: The LUNAR Study. Am. J. Ophthalmol. 2016, 168, 250-259. [CrossRef] [PubMed]

93. Becker, B. The Mechanism of the Fall in Intraocular Pressure Induced by the CARBONIC Anhydrase Inhibitor, Diamox*. Am. J. Ophthalmol. 1955, 39, 177-184. [CrossRef]

94. Sugrue, M.F. Pharmacological and ocular hypotensive properties of topical carbonic anhydrase inhibitors. Prog. Retin. Eye Res. 2000, 19, 87-112. [CrossRef] 
95. Maren, T.H.; Jankowska, L.; Sanyal, G.; Edelhauser, H.F. The transcorneal permeability of sulfonamide carbonic anhydrase inhibitors and their effect on aqueous humor secretion. Exp. Eye Res. 1983, 36, 457-479. [CrossRef]

96. Mincione, F.; Scozzafava, A.; Supuran, C.T. The development of topically acting carbonic anhydrase inhibitors as an-tiglaucoma agents. Curr. Pharm. Des. 2008, 14, 649-654.

97. Kaur, I.P.; Smitha, R.; Aggarwal, D.; Kapil, M. Acetazolamide: Future perspective in topical glaucoma therapeutics. Int. J. Pharm. 2002, 248, 1-14. [CrossRef]

98. Schwartzenberg, G.W.T.; E Trope, G. Anorexia, depression and dementia induced by dorzolamide eyedrops (Trusopt). Can. J. Ophthalmol. 1999, 34, 93-94.

99. Carlsen, J.; Durcan, J.; Zabriskie, N.; Swartz, M.; Crandall, A. Nephrolithiasis with dorzolamide. Arch. Ophthalmol. 1999, 117, 1087-1088. [CrossRef]

100. Mitsuyama, S.; Abe, F.; Higuchi, T. Allergic contact dermatitis due to dorzolamide eyedrops. Contact Dermat. 2021, 84, 58-59. [CrossRef]

101. Gladwin, M.T.; Lancaster, J.R., Jr.; Freeman, B.A.; Schechter, A.N. Nitric oxide's reactions with hemoglobin: A view through the SNO-storm. Nat. Med. 2003, 9, 496-500. [CrossRef] [PubMed]

102. Carpenter, A.W.; Reighard, K.P.; Saavedra, J.E.; Schoenfisch, M.H. O2-Protected diazeniumdiolate-modified silica nanoparticles for extended nitric oxide release from dental composites. Biomater. Sci. 2013, 1, 456-459. [CrossRef]

103. Riccio, D.A.; Schoenfisch, M.H. Nitric oxide release: Part I. Macromolecular scaffolds. Chem. Soc. Rev. 2012, 41, 3731-3741. [CrossRef]

104. Blecher, K.; Martinez, L.R.; Tuckman-Vernon, C.; Nacharaju, P.; Schairer, D.; Chouake, J.; Friedman, J.M.; Alfieri, A.; Guha, C.; Nosanchuk, J.D.; et al. Nitric oxide-releasing nanoparticles accelerate wound healing in NOD-SCID mice. Nanomed. Nanotechnol. Biol. Med. 2012, 8, 1364-1371. [CrossRef]

105. Han, G.; Nguyen, L.N.; Macherla, C.; Chi, Y.; Friedman, J.M.; Nosanchuk, J.D.; Martinez, L.R. Nitric Oxide-Releasing Nanoparticles Accelerate Wound Healing by Promoting Fibroblast Migration and Collagen Deposition. Am. J. Pathol. 2012, 180, 1465-1473. [CrossRef] [PubMed]

106. Pelgrift, R.Y.; Friedman, A.J. Nanotechnology as a therapeutic tool to combat microbial resistance. Adv. Drug Deliv. Rev. 2013, 65, 1803-1815. [CrossRef] [PubMed]

107. Hetrick, E.M.; Shin, J.H.; Stasko, N.A.; Johnson, C.B.; Wespe, D.A.; Holmuhamedov, E.; Schoenfisch, M.H. Bactericidal Efficacy of Nitric Oxide-Releasing Silica Nanoparticles. ACS Nano 2008, 2, 235-246. [CrossRef] [PubMed]

108. Cabrales, P.; Han, G.; Nacharaju, P.; Friedman, A.J.; Friedman, J.M. Reversal of hemoglobin-induced vasoconstriction with sustained release of nitric oxide. Am. J. Physiol. Circ. Physiol. 2011, 300, H49-H56. [CrossRef] [PubMed]

109. Nachuraju, P.; Friedman, A.J.; Friedman, J.M.; Cabrales, P. Exogenous nitric oxide prevents cardiovascular collapse during hemorrhagic shock. Resuscitation 2011, 82, 607-613. [CrossRef] [PubMed]

110. Nacharaju, P.; Tuckman-Vernon, C.; Maier, K.E.; Chouake, J.; Friedman, A.; Cabrales, P.; Friedman, J.M. A nanoparticle delivery vehicle for S-nitroso-N-acetyl cysteine: Sustained vascular response. Nitric Oxide 2012, 27, 150-160. [CrossRef]

111. Johnson, T.A.; Stasko, N.A.; Matthews, J.L.; Cascio, W.E.; Holmuhamedov, E.; Johnson, C.B.; Schoenfisch, M.H. Reduced ischemia/reperfusion injury via glutathione-initiated nitric oxide-releasing dendrimers. Nitric Oxide 2010, 22, 30-36. [CrossRef] [PubMed]

112. Han, G.; Tar, M.; Kuppam, D.S.; Friedman, A.; Melman, A.; Friedman, J.; Davies, K.P. Nanoparticles as a novel delivery vehicle for therapeutics targeting erectile dysfunction. J. Sex. Med. 2010, 7, 224-233. [CrossRef] [PubMed]

113. Duong, H.; Dong, Z.; Su, L.; Boyer, C.; George, J.; Davis, T.P.; Wang, J. The Use of Nanoparticles to Deliver Nitric Oxide to Hepatic Stellate Cells for Treating Liver Fibrosis and Portal Hypertension. Small 2015, 11, 2291-2304. [CrossRef] [PubMed]

114. Napoli, C.; Ignarro, L.J. Nitric oxide and atherosclerosis. Nitric Oxide 2001, 5, 88-97. [CrossRef]

115. Chen, Z.; Zhang, J.; Stamler, J.S. Identification of the enzymatic mechanism of nitroglycerin bioactivation. Proc. Natl. Acad. Sci. USA 2002, 99, 8306-8311. [CrossRef] [PubMed]

116. Sydow, K.; Daiber, A.; Oelze, M.; Chen, Z.; August, M.; Wendt, M.; Ullrich, V.; Mülsch, A.; Schulz, E.; Keaney, J.F., Jr.; et al. Central role of mitochondrial aldehyde dehydrogenase and reactive oxygen species in nitro-glycerin tolerance and cross-tolerance. J. Clin. Investig. 2004, 113, 482-489. [CrossRef]

117. Knott, A.B.; Bossy-Wetzel, E. Nitric Oxide in Health and Disease of the Nervous System. Antioxid. Redox Signal. 2009, 11, 541-553. [CrossRef] [PubMed]

118. Hu, C.; Zhang, Y.; Song, M.; Deng, Y.; Sun, X.; Lei, Y. Prolonged use of nitric oxide donor sodium nitroprusside induces ocular hypertension in mice. Exp. Eye Res. 2021, 202, 108280. [CrossRef] [PubMed] 